\title{
A CHRONOLOGY of the LIFE of MARY HAMPSON
}

1627 Birth of Robert Hampson.

1639, August 5 Birth of Mary Wingfield later Hampson.

1656, August Marriage of Mary Wingfield and Robert Hampson.

1657, April 15 Birth of Elizabeth, first child of Robert and Mary.

1658, July 7 Birth of son Robert.

1658, Autumn Fight between Robert and his sisters. The Hampsons move out of the Holborn Road house, into rooms near Somerset House in central London.

1662, January 29 Birth of daughter Mary.

1663, Summer Robert beats and abandons Mary. She moves to

Richmond in Surrey.

1663, October Birth of daughter Anne.

1664, May or June Mary leaves for France.

1664, August Death of Mary's uncle, John Whalley.

1666, April Mary returns from France and lodges with the Terry family.

1666, July i6 Death of daughter Anne.

1666, September 2 Great Fire of London. Robert's Inner Temple chambers destroyed. 
1667, Spring Mary and Robert move to Robert's new Inner Temple chambers.

1668, February Mary and Robert Hampson reconcile after a four-day fight in January and move to lodgings in St. Martin's Parish, London. 1668, Summer Mary and Robert move to a house in New Southampton Square.

1669, September Death of Mary's mother, Elizabeth Whalley Wingfield. 1669, December Robert leaves Mary and moves to Exeter House. 1670, February I Robert locks Mary out of the New Southampton Square house.

1670, February 28 Robert has Mary's servant Katherine Brown arrested and brings Mary in front of the justice of the peace.

1670, March Court of Arches case commences.

1670, June High Court of Delegates case commences.

1671, May Mary leaves for France after agreeing to a separation from Robert.

1673, November Mary returns to England to secure her alimony.

1673, December Edmund Everard arrested; accuses Mary of trying to poison Robert.

1674, January Mary called before Secretary, Lord Coventry to answer Everard's accusations that she tried to kill Robert.

1674-1677 Mary is living in France.

1674, December Robert claims Mary is dead.

1677 Mary comes to England for a short time and then returns to France.

1680, Spring Mary returns to England to sue Robert for her alimony. 1680, May Mary's suit against Robert for nonpayment of alimony is heard; Mary travels to Amsterdam.

1680-1682 Mary is living in the Netherlands. 
1681 Elizabeth Hampson marries Charles Bill.

1683-1692 Mary lives in Paris and possibly in the Netherlands.

1684 Mary publishes A Plain and Compendious Relation of the Case of Mrs. Mary Hampson (two editions).

1685 Robert publishes A Relation of the Design of Mrs Mary Hampson 1688, December Robert dies and is buried in the Inner Temple. 1692 Mary returns to London.

1698, February 15 Mary dies in the parish of St Bride, London. 


\title{
Hampsons of Taplow, Buckinghamshire
}

\section{Sir Robert Hampson m. Katherine Good}

(4 children including Sir Thomas)

Sir Thomas Hampson m. Anne Duncombe

\author{
1 \\ Thomas m. Mary Dennis \\ Robert m. Mary Wingfield \\ George m. Grace Holte \\ Mary m. John Lawrence \\ Rebecca m. Ambrose Benet \\ Margaret m. Sir Giles Hungerford \\ Ambrose, unmarried \\ Katherine, unmarried \\ Elizabeth, unmarried
}

FIGURE r. Hampson and Wingfield Families. 


\section{Wingfields of Kimbolton Castle, Cambridgeshire}

Sir James Wingfield m I. Elizabeth Brakyn

( 4 children including Sir Edward, the heir)

m 2. Elizabeth Bodenham

( 5 children including Bodenham)

Mr Bodenham Wingfield m. Elizabeth Whalley

Elizabeth (died an infant)

Mary m. Robert Hampson

Robert Hampson m. Mary Wingfield

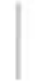

Elizabeth m. Charles Bill

Robert (died an infant)

Anne (died at six)

Mary unmarried 
